\title{
DNA methylation patterns and epigenetic memory
}

\author{
Adrian Bird ${ }^{1}$ \\ Wellcome Trust Centre for Cell Biology, University of Edinburgh, Edinburgh EH9 3JR, UK
}

The character of a cell is defined by its constituent proteins, which are the result of specific patterns of gene expression. Crucial determinants of gene expression patterns are DNA-binding transcription factors that choose genes for transcriptional activation or repression by recognizing the sequence of DNA bases in their promoter regions. Interaction of these factors with their cognate sequences triggers a chain of events, often involving changes in the structure of chromatin, that leads to the assembly of an active transcription complex (e.g., Cosma et al. 1999). But the types of transcription factors present in a cell are not alone sufficient to define its spectrum of gene activity, as the transcriptional potential of a genome can become restricted in a stable manner during development. The constraints imposed by developmental history probably account for the very low efficiency of cloning animals from the nuclei of differentiated cells (Rideout et al. 2001; Wakayama and Yanagimachi 2001). A "transcription factors only" model would predict that the gene expression pattern of a differentiated nucleus would be completely reversible upon exposure to a new spectrum of factors. Although many aspects of expression can be reprogrammed in this way (Gurdon 1999), some marks of differentiation are evidently so stable that immersion in an alien cytoplasm cannot erase the memory.

The genomic sequence of a differentiated cell is thought to be identical in most cases to that of the zygote from which it is descended (mammalian $\mathrm{B}$ and $\mathrm{T}$ cells being an obvious exception). This means that the marks of developmental history are unlikely to be caused by widespread somatic mutation. Processes less irrevocable than mutation fall under the umbrella term "epigenetic" mechanisms. A current definition of epigenetics is: "The study of mitotically and/or meiotically heritable changes in gene function that cannot be explained by changes in DNA sequence" (Russo et al. 1996). There are two epigenetic systems that affect animal development and fulfill the criterion of heritability: DNA methylation and the Polycomb-trithorax group

${ }^{1}$ E-MAIL A.Bird@ed.ac.uk; FAX 0131-650-5379.

Article and publication are at http://www.genesdev.org/cgi/doi/10.1101/ gad.947102.
(Pc-G/trx) protein complexes. (Histone modification has some attributes of an epigenetic process, but the issue of heritability has yet to be resolved.) This review concerns DNA methylation, focusing on the generation, inheritance, and biological significance of genomic methylation patterns in the development of mammals. Data will be discussed favoring the notion that DNA methylation may only affect genes that are already silenced by other mechanisms in the embryo. Embryonic transcription, on the other hand, may cause the exclusion of the DNA methylation machinery. The heritability of methylation states and the secondary nature of the decision to invite or exclude methylation support the idea that DNA methylation is adapted for a specific cellular memory function in development. Indeed, the possibility will be discussed that DNA methylation and Pc-G/trx may represent alternative systems of epigenetic memory that have been interchanged over evolutionary time. Animal DNA methylation has been the subject of several recent reviews (Bird and Wolffe 1999; Bestor 2000; Hsieh 2000; Costello and Plass 2001; Jones and Takai 2001). For recent reviews of plant and fungal DNA methylation, see Finnegan et al. (2000), Martienssen and Colot (2001), and Matzke et al. (2001).

\section{Variable patterns of DNA methylation in animals}

A prerequisite for understanding the function of DNA methylation is knowledge of its distribution in the genome. In animals, the spectrum of methylation levels and patterns is very broad. At the low extreme is the nematode worm Caenorhabditis elegans, whose genome lacks detectable $\mathrm{m}^{5} \mathrm{C}$ and does not encode a conventional DNA methyltransferase. Another invertebrate, the insect Drosophila melanogaster, long thought to be devoid of methylation, has a DNA methyltransferaselike gene (Hung et al. 1999; Tweedie et al. 1999) and is reported to contain very low $\mathrm{m}^{5} \mathrm{C}$ levels (Gowher et al. 2000; Lyko et al. 2000), although mostly in the CpT dinucleotide rather than in $\mathrm{CpG}$, which is the major target for methylation in animals. Most other invertebrate genomes have moderately high levels of methyl-CpG concentrated in large domains of methylated DNA separated by equivalent domains of unmethylated DNA (Bird et al. 1979; Tweedie et al. 1997). This mosaic methylation pattern has been confirmed at higher resolution in the sea 
squirt, Ciona intestinalis (Simmen et al. 1999). At the opposite extreme from C. elegans are the vertebrate genomes, which have the highest levels of $\mathrm{m}^{5} \mathrm{C}$ found in the animal kingdom. Vertebrate methylation is dispersed over much of the genome, a pattern referred to as global methylation. The variety of animal DNA methylation patterns highlights the possibility that different distributions reflect different functions for the DNA methylation system (Colot and Rossignol 1999).

\section{Mammalian DNA methylation patterns vary in time and space}

In human somatic cells, $\mathrm{m}^{5} \mathrm{C}$ accounts for $\sim 1 \%$ of total DNA bases and therefore affects $70 \%-80 \%$ of all CpG dinucleotides in the genome (Ehrlich 1982). This average pattern conceals intriguing temporal and spatial variation. During a discrete phase of early mouse development, methylation levels in the mouse decline sharply to $\sim 30 \%$ of the typical somatic level (Monk et al. 1987; Kafri et al. 1992). De novo methylation restores normal levels by the time of implantation. A much more limited drop in methylation occurs in the frog Xenopus laevis (Stancheva and Meehan 2000), and no drop is seen in the zebrafish, Danio rerio (MacLeod et al. 1999). Even within vertebrates, therefore, interspecies variation is seen that could reflect differences in the precise role played by methylation in these organisms. For mice and probably other mammals, however, the cycle of early embryonic demethylation followed by de novo methylation is critical in determining somatic DNA methylation patterns. A genome-wide reduction in methylation is also seen in primordial germ cells (Tada et al. 1997; Reik et al. 2001) during the proliferative oogonial and spermatogonial stages.

The most striking feature of vertebrate DNA methylation patterns is the presence of CpG islands, that is, unmethylated GC-rich regions that possess high relative densities of CpG and are positioned at the $5^{\prime}$ ends of many human genes (for review, see Bird 1987). Computational analysis of the human genome sequence predicts 29,000 CpG islands (Lander et al. 2001; Venter et al. 2001). Earlier studies estimated that $\sim 60 \%$ of human genes are associated with $\mathrm{CpG}$ islands, of which the great majority are unmethylated at all stages of development and in all tissue types (Antequera and Bird 1993). Because many CpG islands are located at genes that have a tissue-restricted expression pattern, it follows that $\mathrm{CpG}$ islands can remain methylation-free even when their associated gene is silent. For example, the tissuespecifically expressed human $\alpha$-globin (Bird et al. 1987) and $\alpha 2(1)$ collagen (McKeon et al. 1982) genes have CpG islands that remain unmethylated in all tested tissues, regardless of expression.

A small but significant proportion of all CpG islands become methylated during development, and when this happens the associated promoter is stably silent. Developmentally programmed CpG-island methylation of this kind is involved in genomic imprinting and $\mathrm{X}$ chromosome inactivation (see below). The de novo methylation events occur in germ cells or the early embryo (Jaenisch et al. 1982), suggesting that de novo methylation is particularly active at these stages. There is evidence, however, that de novo methylation can also occur in adult somatic cells. A significant fraction of all human CpG islands are prone to progressive methylation in certain tissues during aging (for review, see Issa 2000), or in abnormal cells such as cancers (for review, see Baylin and Herman 2000) and permanent cell lines (Harris 1982; Antequera et al. 1990; Jones et al. 1990). The rate of accumulation of methylated CpGs in somatic cells appears to be very slow. For example, de novo methylation of a provirus in murine erythroleukemia cells took many weeks to complete (Lorincz et al. 2000). Similarly, the recovery of global DNA methylation levels following chronic treatment of mouse cells with the DNA methylation inhibitor 5-azacytidine required months (Flatau et al. 1984).

How do patterns of methylated and unmethylated mammalian DNA arise in development and how are they maintained? Why are CpG islands usually, but not always, methylation-free? What causes methylation of bulk non-CpG-island DNA? These burning questions cannot be answered definitively at present, but there are distinct hypotheses that have been addressed experimentally. The available data will be conveniently considered in three parts: (1) mechanisms for maintaining DNA methylation patterns; (2) mechanisms and consequences of methylation gain; and (3) mechanisms and consequences of methylation loss.

\section{Maintenance methylation-not so simple}

Maintenance methylation describes the processes that reproduce DNA methylation patterns between cell generations. The simplest conceivable mechanism for maintenance depends on semiconservative copying of the parental-strand methylation pattern onto the progeny DNA strand (Holliday and Pugh 1975; Riggs 1975). In keeping with the model, the methylating enzyme DNMT1 prefers to methylate those new CpGs whose partners on the parental strand already carry a methyl group (Bestor 1992; Pradhan et al. 1999). Thus a pattern of methylated and nonmethylated CpGs along a DNA strand tends to be copied, and this provides a way of passing epigenetic information between cell generations. The idea that mammalian DNA methylation patterns are established in early development by de novo methyltransferases DNMT3A and DNMT3B (Okano et al. 1998a, 1999; Hsieh 1999b) and then copied to somatic cells by the maintenance DNA methyltransferase DNMT1 is elegant and simple, but, as discussed below, may not fully explain persistence of methylation patterns during cell proliferation.

Experiments that first showed replication of methylation patterns on artificially methylated DNA also revealed a relatively low fidelity for the process (Pollack et al. 1980; Wigler et al. 1981). After many cell generations, methylation of the introduced DNA was retained, but at a much lower level than in the starting plasmid. The 
failure of maintenance was estimated to occur with a frequency of $\sim 5 \%$ per CpG site per cell division. Quantitative studies of an endogenous CpG site broadly agreed with this figure (Riggs et al. 1998). Cell clones in which this site was initially unmethylated acquired methylation and clones where it was methylated lost methylation. The rate of change was estimated at $\sim 4 \%$ per cell generation. Error rates of this magnitude mean that a detailed methylation pattern would eventually become indistinct as cells proliferate. Indeed, dynamic changes in detailed methylation patterns have been observed in monoclonal lyomyomas (Silva et al. 1993) and at the methylated FMR1 gene (Stöger et al. 1997). These studies established that clonal populations of cells do not have the homogeneous methylation patterns that would be predicted by the replication model of maintenance methylation. Not only does DNA methyltransferase fail to complete half-methylated sites at a significant rate, but also significant de novo methylation occurs at unmethylated sites.

At first sight, these findings appear to undermine the concept of maintenance methylation, but this does not follow. Although detailed methylation patterns may not be maintained at the level of a single CpG nucleotide, the methylation status of DNA domains appears to be faithfully propagated during development (Pfeifer et al. 1990). CpG islands, for example, keep their overall unmethylated state (or methylated state) extremely stably through multiple cell generations. DNMT1 is partly responsible for this stability, but there is likely to be another as yet unknown component to the maintenance process. Dramatic evidence for this alternative maintenance mechanism comes from the finding that CpG-island methylation is stably maintained even in the apparent absence of the only known maintenance DNA methyltransferase, DNMT1 (Rhee et al. 2000). A similar phenomenon may account for the maintenance of allelespecific DNA methylation imprints under conditions where the concentration of DNMT1 is severely limiting (Jaenisch 1997).

\section{De novo DNA methylation by default?}

The origin of DNA methylation patterns is a long-standing mystery in the field. The de novo methyltransferases DNMT3A and DNMT3B (Okano et al. 1998a, 1999) are highly expressed in early embryonic cells, and it is at this stage that most programmed de novo methylation events occur. What determines which regions of the genome should be methylated? An extreme possibility is that de novo DNA methylation in early mammalian development is an indiscriminate process potentially affecting all CpGs. Compatible with the default model is the apparent absence of intrinsically unmethylatable DNA sequences in mammalian genomes. Even CpG islands, most of which are unmethylated at all times in normal cells, can acquire methylation under special developmental circumstances or in abnormal cells (permanent cell lines or cancer cells). It is clear, however, that not all regions of the genome are equally accessible to DNA methyltransferases. DNMT3B in particular is known to be required for de novo methylation of specific genomic regions, as mice or human patients with DNMT3B mutations are deficient in methylation of pericentromeric repetitive DNA sequences and at $\mathrm{CpG}$ islands on the inactive X chromosome (Miniou et al. 1994; Okano et al. 1998b; Hansen et al. 2000; Kondo et al. 2000). DNMT3B may therefore be adapted to methylate regions of silent chromatin.

Evidence that accessory factors are also needed to ensure appropriate methylation came initially from plants, where the SNF2-like protein DDM1 was shown to be essential for full methylation of the Arabidopsis thaliana genome (Jeddeloh et al. 1999). An equivalent dependence is seen in animals, as mutations in human ATRX (Gibbons et al. 2000) and mouse Lsh2 genes (Dennis et al. 2001), both of which encode relatives of the chromatin-remodeling protein SNF2, have significant effects on global DNA methylation patterns. Loss of LSH2 protein, in particular, matches the phenotype of the DDM1 mutation in Arabidopsis, for both mutants lose methylation of highly repetitive DNA sequences, but retain some methylation elsewhere in the genome. Perhaps efficient global methylation of the genome requires perturbation of chromatin structure by these chromatinremodeling proteins so that DNMTs can gain access to the DNA. Collaboration between DNMTs and factors that allow them access to specialized chromosomal regions may be particularly important in regions that are heterochromatic and inaccessible. Although the net result of these processes is apparently global genomic methylation, the evidence for selectivity means that the word "default" is probably not appropriate.

\section{Targeting de novo methylation to preferred DNA sequences}

Another hypothesis to explain global methylation is that the DNA methylation machinery is preferentially attracted by certain DNA sequences in the mammalian genome (Turker 1999). The presence of high levels of methylation in DNA outside such a DNA methylation center could be explained by spreading into the surrounding DNA. Barriers to spreading would lead to the formation of $\mathrm{CpG}$ islands. A hypothetical trigger for DNA methylation is DNA sequence repetition, which can promote de novo methylation in filamentous fungi and plants under certain circumstances (Selker 1999; Martienssen and Colot 2001). The most suggestive evidence in mammals concerns manipulation of transgene copy number at a single locus in the mouse genome using cre-lox technology (Garrick et al. 1998). High levels of transgene repetition were found to cause significant transgene silencing and concomitant methylation. The efficiency of expression increased as copy number was reduced at the locus, and the level of methylation decreased. Whether repetition caused methylation directly, or indirectly as a consequence of some other event (e.g., transcriptional silencing; see below), is not known.

The clearest definition of a DNA methylation center 
comes from the fungus Neurospora, where short TpArich segments of DNA were found to induce methylation (Miao et al. 2000). Identification of a mammalian DNA methylation center located upstream of the mouse adenine phophoribosyltransferase (APRT) gene has been reported (Mummaneni et al. 1993; Yates et al. 1999). The region contains $\mathrm{B} 1$ repetitive elements and attracts high levels of de novo methylation upon transfection into embryonic cells, although the effect is relative, because many DNA sequences are subject to de novo methylation in these cells. The APRT methylation center becomes methylated in DNMT1-deficient ES cells, supporting the idea that it corresponds to a region that is a favorable substrate for de novo methylation (Yates et al. 1999).

Because the evidence suggests that replication of methylation patterns by DNMT1 is only partly responsible for maintenance methylation (see above), an attractive possibility is that the features of a DNA domain that help maintain its methylated status are the same features that promote its de novo methylation. Imprinting boxes, for example, whose differential methylation is associated with genomic imprinting (Tremblay et al. 1997; Birger et al. 1999; Shemer et al. 2000), tend to retain their methylation levels tenaciously even when the amount of the maintenance enzyme DNMT1 is reduced (Beard et al. 1995). The de novo methylases DNMT3A and DNMT3B (Okano et al. 1998a, 1999) may be attracted disproportionately to these sequences, and this attraction may also underlie the decision to methylate the box in the first place. In other words, de novo methylation may not occur once at a discrete and perhaps rather inaccessible stage of germ-cell development, but may happen repeatedly (assisted by DNMT1) as embryonic cells divide.

\section{Unusual DNA structures and RNAi as triggers for de novo methylation}

Studies of purified DNMT1 revealed that the enzyme prefers to methylate unusual DNA structures in vitro (Smith et al. 1991; Laayoun and Smith 1995). This led to the idea that such structures might be generated during recombination between repetitive elements or during transposition events and directly trigger de novo methylation (Bestor and Tycko 1996). Subsequent evidence, however, does not support a role for DNMT1 in de novo methylation in vivo (Lyko et al. 1999; Howell et al. 2001), and therefore the biological significance of its predilection for deformed DNA is uncertain. There is evidence for transfer of methylation from one copy of a sequence to a second previously unmethylated copy of the same sequence in the fungus Ascobolus (Colot et al. 1996). The process might use mechanisms involved in homologous DNA recombination and may therefore involve deformation of DNA. How identical sequences sense one another and transfer epigenetic information remains unknown, however.

Exciting recent developments in the DNA methylation field have arisen through molecular genetic studies of posttranscriptional gene silencing in plants. Doublestranded RNA directs the destruction of transcripts containing the same sequence, but there is compelling evidence that it can also direct de novo methylation of homologous genomic DNA (Wassenegger et al. 1994; Bender 2001; Matzke et al. 2001). Posttranscriptional gene silencing by double-stranded RNA is probably an ancient genome defence system because it occurs in fungi, plants, and animals; but DNA methylation is not an obligatory accompaniment, as silencing is efficient in C. elegans in the complete absence of genomic $\mathrm{m}^{5} \mathrm{C}$. Even in the fungus Neurospora, where transgene arrays are often methylated, DNA methylation is not required for posttranscriptional gene silencing (or quelling; Cogoni et al. 1996). There are also specific features of RNAdirected DNA methylation that may not occur in animals; notably the occurrence of methylation at multiple non-CpG cytosines in an affected DNA sequence tract. Although there is evidence for non-CpG methylation in ES cells, most probably owing to DNMT3A, which strongly methylates CpA as well as CpG (Ramsahoye et al. 2000; Gowher and Jeltsch 2001), non-CpG methylation is barely detectable in adult cells (Ramsahoye et al. 2000). Plants have a CpG methylation system, but it does not appear to be essential for RNA-directed gene silencing (for reviews, see Wassenegger et al. 1994; Bender 2001; Matzke et al. 2001). Optimism that RNAdirected de novo methylation will also apply in mammals is tempered by this sequence disparity, and by the absence so far of a clear demonstration that mammalian double-stranded RNA leads to DNA methylation-mediated gene silencing.

\section{Transcriptionally silent chromatin as a de novo methylation target}

Several lines of evidence suggest that DNA methylation does not intervene to silence active promoters, but affects genes that are already silent. It was reported many years ago that retroviral transcription is repressed in embryonic cells at $\sim 2 \mathrm{~d}$ after infection, whereas de novo methylation is delayed until $\sim 15 \mathrm{~d}$ (Gautsch and Wilson 1983; Niwa et al. 1983). De novo methylation of proviral sequences in embryo cells depends on DNMT3A and DNMT3B (Okano et al. 1999), but initial retroviral shutdown occurs as usual even when both these de novo methyltransferases are absent (Pannell et al. 2000). Clearly, de novo methylation is not required for silencing in the first instance, reinforcing the view that methylation is a secondary event.

Methylation of genes that are already silent is also observed during $\mathrm{X}$ chromosome inactivation in the mammalian embryo. Kinetic studies showed that the phosphoglycerate kinase gene is silent on the mammalian inactive $\mathrm{X}$ chromosome before methylation of its CpG-island promoters occurs (Lock et al. 1987). Subsequent studies of the mouse, in which the process is best understood, have established that expression of a noncoding chromosomal RNA from the Xist gene on the inactive $\mathrm{X}$ chromosome triggers the inactivation process 
in cis. Specifically, activation of the Xist gene and onset of its late replication precede CpG-island methylation by several days (Keohane et al. 1996; Wutz and Jaenisch 2000). In other words, methylation affects the X chromosome on which genes are already shut down by other mechanisms. Is transcriptional inertia during embryogenesis the trigger for de novo methylation? Studies of the origin of methylation-free CpG islands offer some support for this idea. The coincidence between CpG islands and promoters is striking (Bird 1987), and footprinting shows that the $5^{\prime}$ extremity of CpG islands often corresponds to the region occupied by transcription factors in vivo (Cuadrado et al. 2001). Even when CpG islands are identified in unusual locations, they have turned out to correspond to promoters. For example, a $\mathrm{CpG}$ island located in intron 2 of the Igf2r gene is an active promoter (Wutz et al. 1997; Lyle et al. 2000), as is a CpG island that covers exon 2 of the class II major histocompatibility gene (MacLeod et al. 1998). The potential importance of promoter function in the genesis of $\mathrm{CpG}$ islands is highlighted by studies in transgenic mice. CpG-island-containing transgenes normally faithful reproduce their methylation-free character, but their immunity to methylation is lost if promoter function is impaired (Brandeis et al. 1994; MacLeod et al. 1994). Similarly, viral DNA integrated into ES cell genomes by homologous recombination becomes methylated when the promoter is weakened by absence of an enhancer, but excludes methylation when an enhancer is present (Hertz et al. 1999). A parsimonious interpretation of the results is that failure to transcribe invites de novo methylation (see Fig. 2 below), although other potential explanations (Brandeis et al. 1994; Mummaneni et al. 1998) cannot be discounted.

The signal for this putative gene silence-related de novo methylation is unknown, but the possibility that chromatin states inform the DNA methylation machinery is attractive (Selker 1990). The acetylation and methylation state of nucleosomal histones is tightly correlated with transcriptional activity (Jenuwein and Allis 2001) and could be read by the methylation machinery, leading it to either methylate or fail to methylate a particular domain. Indeed, recent work on Neurospora (Tamaru and Selker 2001) has shown an intimate link between histone methylation and DNA methylation in that fungus, as mutation of a histone methyltransferase that methylates Lys 9 of histone $\mathrm{H} 3$ abolished genomic methylation. In mammalian and yeast systems, histone H3 Lys 9 methylation is associated with transcriptionally repressed heterochromatin (Bannister et al. 2001; Nakayama et al. 2001; Noma et al. 2001; Zhang and Reinberg 2001). If the dependence of DNA methylation on prior histone methylation turns out to be applicable to mammals, this would further strengthen the argument that DNA methylation is targeted to genes that are already silent. The nature of the molecular cues that trigger transfer of methyl groups to unmethylated DNA should be illuminated by ongoing studies of multiprotein complexes that contain DNA methyltransferases (Fuks et al. 2000, 2001; Robertson et al. 2000; Bachman et al. 2001) and the identification of genes that modify DNA methylation patterns (Weng et al. 1995).

\section{Consequences of methylation gain: stable transcriptional silencing of genes}

Why methylate genes that are already silent? A plausible answer is: to silence them irrevocably. Methylation clearly contributes to the stability of inactivation, because both X inactivation (Mohandas et al. 1981a; Graves 1982; Venolia et al. 1982) and retroviral silencing (Stewart et al. 1982; Jaenisch et al. 1985) can be relieved by treatment of somatic cells with demethylating agents. Individuals who lack DNMT3B show reduced methylation of some CpG islands on the inactive X chromosome and also silence X-linked genes imperfectly (Miniou et al. 1994; Hansen et al. 2000). The implication that irreversibility involves DNA methylation is supported by the frequent reactivation of an X-linked transgene in mouse embryo cells and in cultured somatic cells when DNMT1 is absent or inhibited (Sado et al. 2000). This view is sustained by differences in the stability of inactivity states pre- and postmethylation. For example, $\mathrm{X}$ inactivation caused by expression of an Xist transgene in embryonic stem cells is initially reversed when the Xist gene is shut down, but after $3 \mathrm{~d}$, inactivation becomes irreversible and independent of Xist (Wutz and Jaenisch 2000). Irreversibility may reflect the arrival of promoter methylation.

In artificial systems, DNA methylation represses transcription in a manner that depends on the location and density of the methyl-CpGs relative to the promoter (Boyes and Bird 1992; Hsieh 1994; Kass et al. 1997a,b). But what genes are affected by DNA methylation-mediated gene silencing? Early studies relied on the use of the demethylating drug 5-azacytidine (Jones and Taylor 1980), which was shown to activate genes on the inactive $\mathrm{X}$ in rodent-human cell hybrids (Mohandas et al. 1981b; Graves 1982). More recently, mice and murine cell lines lacking DNMT1 (Li et al. 1992) have clarified the effects of DNA methylation on gene expression. In placental mammals, repression of X-linked genes follows expression of Xist, which sets in train the inactivation process, culminating in widespread methylation of CpG islands. The active $\mathrm{X}$ chromosome, on the other hand, must be protected from silencing, and this requires repression of Xist and again depends on methylation (Panning and Jaenisch 1996). An intact DNA methylation system is also essential for genomic imprinting, because deletion of Dnmt1 leads to disruption of the monoallelic expression of several imprinted genes (Li et al. 1993).

Both $\mathrm{X}$ inactivation and genomic imprinting involve silencing of one allele only, leaving the other unaffected. An unusual set of genes that are active in the germ line, most of which are X-linked, appears to use methylation for complete silencing in somatic cells (De Smet et al. 1996, 1999). Several of the human and murine MAGE genes, for example, have CpG-island promoters that are 
methylation-free in germ cells, but are methylated in somatic cells of the adult. The genes were discovered as novel antigens in tumors, where genomic methylation levels are often low and MAGE-gene CpG islands are undermethylated. MAGE expression can be induced by treating nonexpressing cells with demethylating agents, supporting the idea that methylation is an important component of the repression of these genes in somatic cells.

\section{Transposable element silencing as a consequence of DNA methylation}

Another well-documented consequence of DNA methylation deficiency is the activation of transposable element-derived promoters. Like much of the mammalian genome, transposable element-related sequences are heavily methylated and transcriptionally silent in somatic cells. Mouse cells, for example, normally repress transcription of intracisternal A particle (IAP) elements, which constitute a homogeneous and transpositionally active family of elements. In embryos lacking DNMT1, transcription of IAP elements is massively induced, arguing that methylation is normally responsible for their repression (Walsh et al. 1998). Derepression of LINE (Woodcock et al. 1997) and SINE (Liu et al. 1994) promoters in the human genome also occurs when DNA methylation is reduced. The most abundant SINE in the human genome is the Alu family, which consists of several hundred thousand elements (Smit 1999). Only a tiny minority of elements are capable of transposition $(<1 \%)$, but many carry functional promoters. Interestingly, these promoters can be activated by stress of various kinds without altering DNA methylation (Liu et al. 1995; Chu et al. 1998), although artificial demethylation also stimulates expression.

The biological significance of transposable-element repression is uncertain. Two kinds of explanation have been discussed: either that repression is required to prevent DNA damage due to unconstrained transposition (the genome defence model; Yoder et al. 1997); or that transcription of a large excess of irrelevant promoters would constitute an unacceptable level of transcriptional noise that would interfere with gene expression programs (Bird 1995). Increased transcription of elements in human and mouse cells has not so far been found to lead to increased transposition. In undermethylated cancer cells that show transposon promoter activity, for example, mutations caused by transposition are exceedingly rare. It has, however, been claimed that rampant transposition and reduced methylation are linked in the case of an interspecific hybrid marsupial (Waugh O'Neill et al. 1998). The hybrid wallaby concerned was found to contain an abundant transposable element near the centromeres of one parental chromosome set, but not the other. Surprisingly, this element could not be detected in either of the presumed parent species, and was therefore hypothesized to have been assembled from related fragments in the parental genomes following fertilization. It was suggested that, because of perceived depression of methylation levels in the hybrid embryo, the emergent element became transpositionally hyperactive, being targeted exclusively to one parental genome. The parents of the hybrid were not available to verify this unprecedented scenario.

Phylogenetic studies of genomic methylation patterns in animals have not yet offered support for the genome defence model. Effective silencing due to sequence repetition has been observed in Drosophila and C. elegans, but it is associated with the polycomb group of proteins or posttranscriptional gene silencing (Birchler et al. 2000). The possibility that the low level of $\mathrm{m}^{5} \mathrm{C}$ in Drosophila (Lyko et al. 2000) is relevant to silencing has not yet been addressed. Studies of the sea squirt $C$. intestinalis, a chordate belonging to the same phylum as vertebrates, but which does not exhibit global methylation of the genome, revealed that genes were often present in domains of methylated DNA, whereas transposable element families, some of which appeared to be mobile in the population, were unmethylated (Simmen et al. 1999). This is the opposite of expectation, but may represent a frequent situation in invertebrates, which account for $>95 \%$ of animal species (Tweedie et al. 1997).

Colonization of the genome by transposable elements can only occur in the germ-cell lineage because somatic transposition events leave no heritable trace. Paradoxically, transposable elements are often transcriptionally active and unmethylated in germ cells and totipotent ES cells (for review, see Bird 1997). IAP elements, for example, become unmethylated during the gonial proliferation phase, when primordial germ cell number increases from $\sim 75$ to $\sim 25,000$ (Walsh et al. 1998). The frequent absence of DNA methylation in germ cells, when transposition can do long-term damage (Malik et al. 1999|, contrasts with its repressive presence in somatic cells, where transposition would be an evolutionary dead end. It is too early to discount the possibility that transposon promoters, most of which belong to degenerate elements that are incapable of transposition, must be silenced to suppress transcriptional noise.

\section{Mechanisms of DNA methylation-mediated transcriptional repression}

Why does DNA methylation interfere with transcription? Two modes of repression can be envisaged, and it is likely that both are biologically relevant. The first mode involves direct interference of the methyl group in binding of a protein to its cognate DNA sequence (Fig. 1). Many factors are known to bind CpG-containing sequences, and some of these fail to bind when the CpG is methylated. Strong evidence for involvement of this mechanism in gene regulation comes from studies of the role of the CTCF protein in imprinting at the H19/Igf2 locus in mice (Bell and Felsenfeld 2000; Hark et al. 2000; Szabo et al. 2000; Holmgren et al. 2001). CTCF is associated with transcriptional domain boundaries (Bell et al. 1999) and can insulate a promoter from the influence of remote enhancers. The maternally derived copy of the Igf2 gene is silent owing to the binding of CTCF between 
Figure 1. Mechanisms of transcriptional repression by DNA methylation. A stretch of nucleosomal DNA is shown with all CpGs methylated (red circles). Below the diagram is a transcription factor that is unable to bind its recognition site when a methylated $\mathrm{CpG}$ is within it. Many transcription factors are repelled by methylation, including the boundary element protein CTCF (see text). Above the line are protein complexes that can be attracted by methylation, including the methyl-CpGbinding protein MeCP2 (plus the Sin3A histone deacetylase complex), the MeCP1 complex comprising MBD2 plus the NuRD corepressor complex, and the uncharacterized MBD1 and Kaiso complexes. MeCP2 and MBD1 are chromosomebound proteins, whereas MeCP1 may be less tightly bound. Kaiso has not yet been shown to associate with methylated sites in vivo.

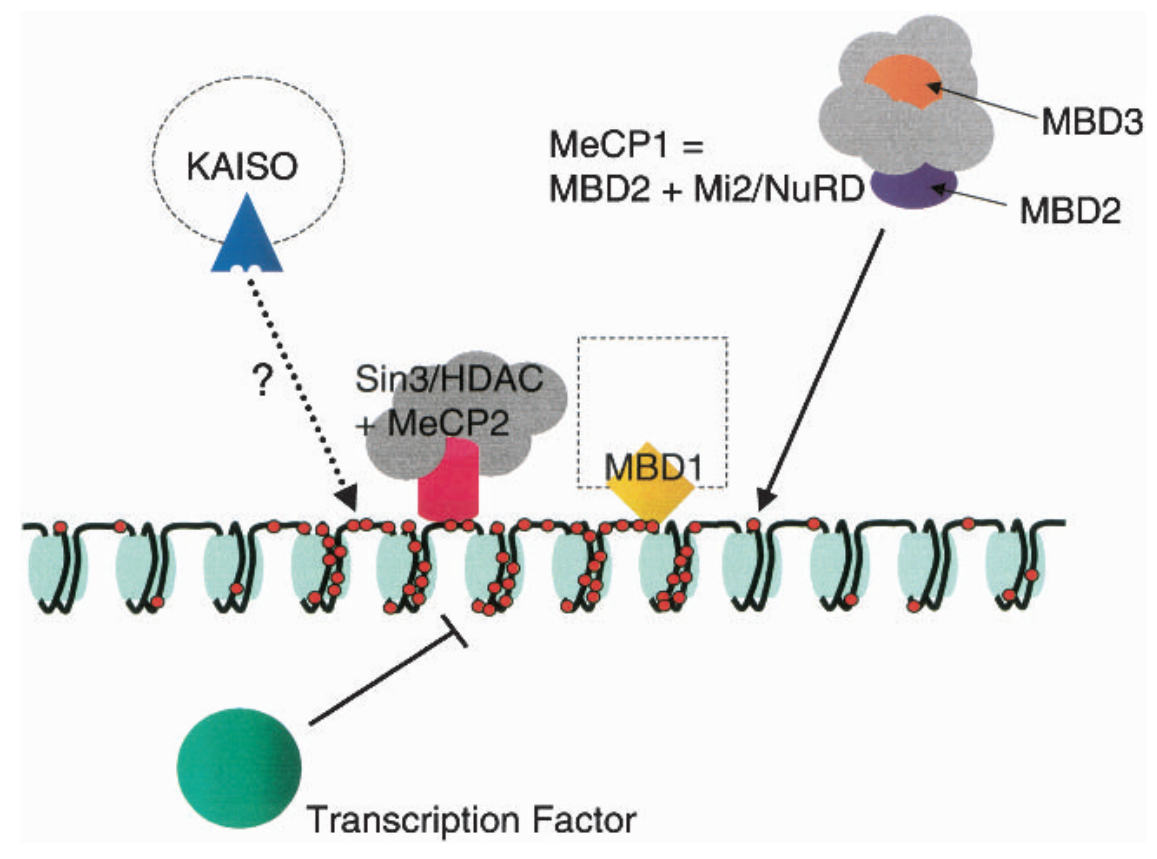

its promoter and a downstream enhancer. At the paternal locus, however, these CpG-rich binding sites are methylated, preventing CTCF binding and thereby allowing the downstream enhancer to activate Igf2 expression. Although there is evidence that H19/Igf2 imprinting involves additional processes (Ferguson-Smith and Surani 2001), the role of CTCF represents one of the clearest examples of transcriptional regulation by DNA methylation.

The second mode of repression is opposite to the first, as it involves proteins that are attracted to, rather than repelled by, methyl-CpG (Fig. 1). A family of five methylCpG-binding proteins has been characterized that each contains a region closely related to the methyl-CpGbinding domain (MBD) of MeCP2 (Nan et al. 1993, 1997; Cross et al. 1997; Hendrich and Bird 1998). Four of these proteins-MBD1, MBD2, MBD3, and MeCP2-have been implicated in methylation-dependent repression of transcription (for review, see Bird and Wolffe 1999). An unrelated protein Kaiso has also recently been shown to bind methylated DNA and bring about methylation-dependent repression in model systems (Prokhortchouk et al. 2001). In vitro, Kaiso requires a $5^{\prime} \mathrm{m}^{5} \mathrm{CGm}{ }^{5} \mathrm{CG}$ motif, and binding is highly dependent on the presence of methylation. The presence of multiple methyl-CpG-binding proteins with repressive properties supports the argument that these may be important mediators of the methylation signal, but their involvement in specific processes that require transduction of the DNA methylation signal has yet to be shown. Targeted mutation of the gene for MeCP2 is, however, associated with neurological dysfunction in humans and mice (Amir et al. 1999; Chen et al. 2001; Guy et al. 2001), and mutation of the mouse $M b d 2$ gene leads to a maternal behavior defect (Hendrich et al. 2001).

\section{Excluding DNA methylation by denying access}

The preceding discussion has considered some mechanistic aspects of de novo DNA methylation and its biological consequences. Although methylation affects most of the mammalian genome, it is conspicuously absent from certain regions. Ways in which these nonmethylated domains may arise will now be considered. A simple mechanism for creating a nonmethylated domain within an otherwise densely methylated genome is to mask a stretch of DNA by protein binding. The DNAbinding protein would accomplish this passive demethylation by, for example, sterically excluding DNMTs (Bird 1986). The feasibility of this mechanism has been verified using an artificially methylated episome containing EBNA1 or lac repressor binding sites (Hsieh 1999a; Lin et al. 2000). The idea that CpG islands are entirely attributable to exclusion of this kind is in doubt, however, as in vivo footprinting and nuclease accessibility studies show CpG islands to be more accessible to proteins (nucleases) than bulk genomic DNA, not less (Tazi and Bird 1990). Of course, it is possible that protection is only present at the transient embryonic stage when mammalian de novo methylation occurs and has therefore escaped detection. A protein that is reported to bind unmethylated CpGs might be a candidate CpG-island protector (Voo et al. 2000).

\section{Immunity to DNA methylation caused by transcriptionally active chromatin: the origin of unmethylated CpG islands}

Many of the known biological effects of DNA methylation are associated with CpG islands. It has been argued above that their methylation in the early embryo follows 
silencing events that are likely to be DNA methylationindependent. If transcriptional silence indeed triggers DNA methylation, then the corollary is that promoter activity early in development should create a methylation-free CpG island (Fig. 2). In other words, unmethylated $\mathrm{CpG}$ islands might be footprints of embryonic promoter activity. An obvious prediction of this model is that all unmethylated $\mathrm{CpG}$ islands, including those at promoters of highly tissue-specifically expressed genes, should contain promoters that function during early development when the methylation memory system is most active. Although very limited, the data so far favor this theory, because a CpG-island promoter whose product RNA is not expected to occur in the early embryo $(\alpha$-globin $)$ is nevertheless expressed, whereas transcripts from a CpG-deficient promoter ( $\beta$-globin) are not detected (Daniels et al. 1997). Similarly, expression of the 68k neurofilament gene, which has a CpG-island promoter, was detected in ES cells, but opsin and casein genes, which are $\mathrm{CpG}$-deficient genes, appeared to be silent (MacLeod et al. 1998).
Why should active promoter regions escape de novo methylation? $\mathrm{CpG}$ islands often colocalize with origins of DNA replication (Delgado et al. 1998), and, according to one speculation, an early replication intermediate creates the DNA methylation-free footprint (Antequera and Bird 1999). A more direct (but not mutually exclusive) mechanism would involve the sensing of chromatin states by the de novo methylation system as discussed above. Whereas histone H3 tails modified by methylation on Lys 9 might recruit DNA methyltransferases (Tamaru and Selker 2001), modifications associated with active chromatin, such as acetylation of $\mathrm{H} 3$ or $\mathrm{H} 4$ or methylation of Lys 4 of histone $\mathrm{H} 3$, may actively exclude these enzymes. Biochemical evidence addressing this issue is eagerly awaited.

\section{Active demethylation of DNA}

Protection against de novo methylation by bound proteins or chromatin can ensure that DNA methylation never reaches a DNA sequence domain. Unmethylated

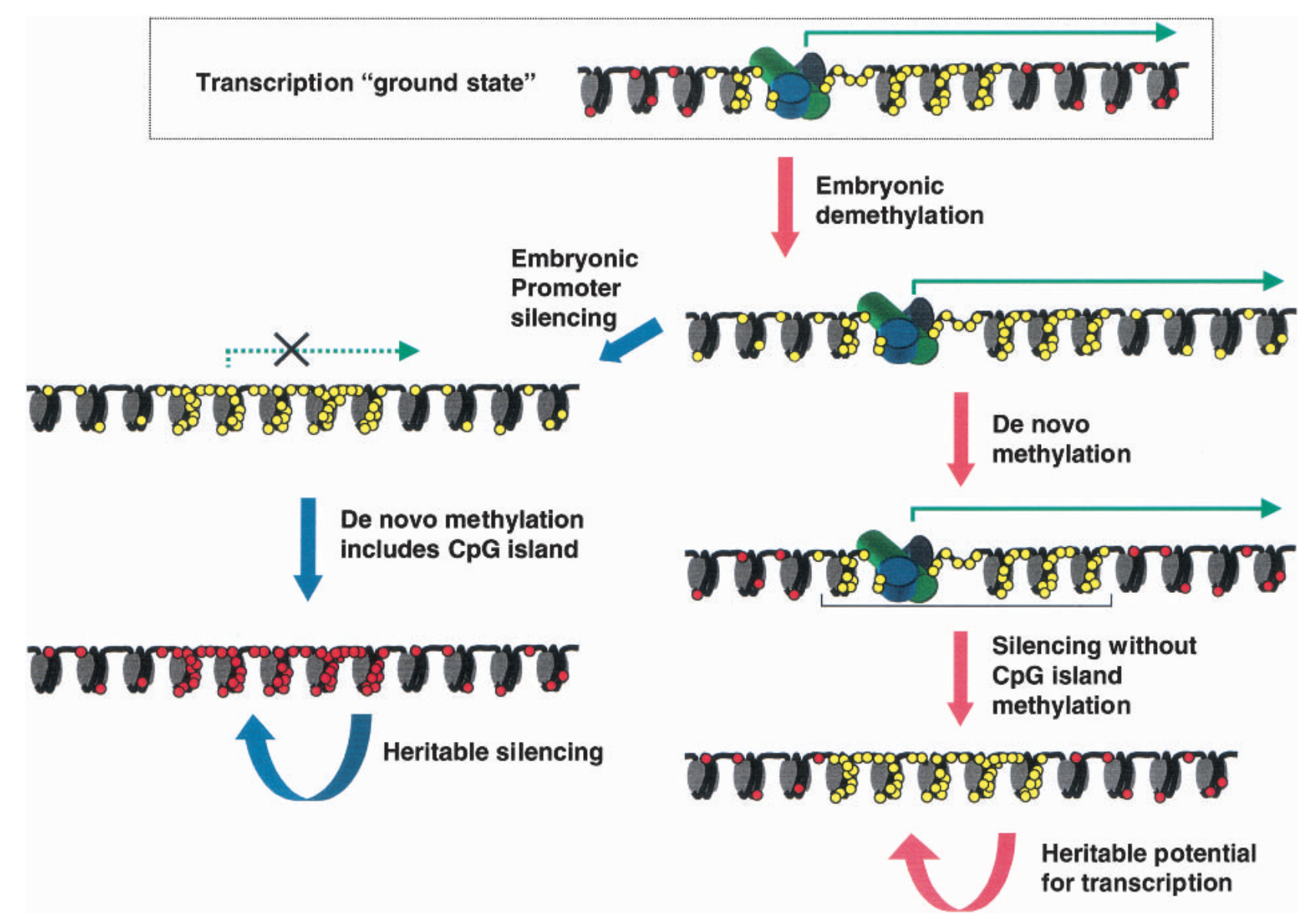

Figure 2. A hypothetical scenario relating embryonic transcriptional activity to DNA methylation status in mammals. Starting from a notional transcription ground state, embryonic demethylation leads to substitution of methylated sites (red circles) by nonmethylated sites (yellow circles). Two alternative fates are then envisaged: either transcription persists leading to restoration of the unmethylated CpG island (bracket) flanked by methylated non-island-flanking DNA (pink arrows); or transcription is extinguished by other mechanisms in the embryo and this invites de novo methylation of the CpG island and its flanks. In this way the activity of embryonic promoters is imprinted for the duration of that somatic lifetime. 
domains could also arise by actively removing the modification from DNA. This so-called active demethylation could be accomplished either by the thermodynamically unfavorable breakage of the carbon-carbon bond that links the pyrimidine to its methyl group, or by a repairlike process that excises the $\mathrm{m}^{5} \mathrm{C}$ base or nucleoside, leading to its replacement with C (Kress et al. 2001). Several laboratories have striven to isolate demethylase enzymes (for review, see Wolffe et al. 1999). The most impressive catalytic activity was shown by a fraction derived from human cells (Ramchandani et al. 1999) that was subsequently identified as MBD2 (Bhattacharya et al. 1999). The expressed protein reportedly showed robust demethylation in vitro in the absence of added cofactors and released methanol as a by-product. Attempts to observe this property of MBD2 in other laboratories have not been successful.

A cell extract showing demethylase activity was detected in rat myoblast cells (Weiss et al. 1996). Initial indications that the reaction was RNA-dependent were not sustained upon further enrichment of the activity (Swisher et al. 1998). An RNA-containing demethylating complex was, however, reported in chicken cells (Jost et al. 1997, 1999). These investigators searched for proteins with $\mathrm{m}^{5} \mathrm{C}$-DNA glycosylase activity and identified the previously known thymine DNA glycosylase TDG, which can remove the pyrimidine base from T:G or $\mathrm{U}: \mathrm{G}$ mismatches (Zhu et al. 2000b). MBD4, an unrelated DNA glycosylase with similar properties, was also found to be active against $\mathrm{m}^{5} \mathrm{C}: \mathrm{G}$ pairs (Zhu et al. 2000a). As the efficiency of these reactions was much lower than that seen with the cognate mismatched substrates, it might be argued that the $\mathrm{m}^{5} \mathrm{C}$ glycosylase activity represents a minor side reaction of little in vivo significance. Set against this is evidence that stable expression of a chicken TDG results in significant activation and concomitant demethylation of a reporter gene driven by a methylated ecdysone-retinoic acid-responsive promoter (Zhu et al. 2001). The normally silent reporter could also be activated by demethylation with 5-azacytidine, but generalized demethylation of the genome was not observed in TDG transfected cells. Previous studies showed an association between retinoid receptors and TDG, and implicated TDG in transcriptional activation (Um et al. 1998). Time will tell if the stimulation of retinoid-responsive promoters by TDG depends on its demethylating activity.

The need to isolate demethylating enzymes has become more acute with the finding that the paternal genome is subject to active demethylation soon after fertilization (Mayer et al. 2000; Oswald et al. 2000). Similar processes have been reported in pig and bovine embryos (Bourc'his et al. 2001; Kang et al. 2001a,b). This dramatic illustration of methylation loss in the absence of DNA replication raises questions about the prevalence of demethylation by this mechanism. Interestingly, the maternal genome, which also demethylates during early mouse development, does so by a different mechanism: passive failure to methylate progeny stands (Rougier et al. 1998). Why should maternal and paternal genomes choose such different routes to the same end? An intriguing possibility is that the parental struggle over maternal resources for the embryo that is thought to underlie genomic imprinting (Moore and Haig 1991) may be involved. The oocyte may be equipped to directly disarm the sperm genome of methylation imprints that might overexploit maternal resources (Reik and Walter 2001). It is even possible that the paternal genome, in delayed retaliation, may organize a campaign of interference with the maintenance methylation (e.g., by exporting maternal DNMTs to the cytoplasm). The extraordinary need for an oocyte variant of DNMT1 to translocate into the nucleus for only one cleavage cycle (the doubling from 8 to 16 cells; Howell et al. 2001) could represent maternal measures to compensate for interference of this kind.

\section{Consequences of methylation loss: gene activation during development}

Interest in DNA methylation has long been fueled by the notion that strategic loss of methyl groups during development could lead to activation of specific genes in the appropriate lineage. As has been emphasized (Walsh and Bestor 1999|, much of the evidence for this scenario is inconclusive, but recent studies have revived the idea. In the frog, gene expression is suppressed from fertilization until the mid-blastula stage ( 5000 cells), at which time transcription is activated. Inhibition of DNMT1 using an antisense strategy caused reduced methylation and premature activation of certain genes, suggesting a direct role for DNA methylation in maintaining their early silence prior to the blastula stage (Stancheva and Meehan 2000). Deletion of the Dnmt1 gene in cultured somatic cells of the mouse also caused widespread gene activation (Jackson-Grusby et al. 2001). About 10\% of all genes detected using microarray technology were activated, whereas only $1 \%-2 \%$ were down-regulated. Some of the up-regulated genes are normally only expressed in terminally differentiated cells. These findings raise the possibility that DNA methylation contributes to silencing of tissue-specific genes in nonexpressing cells, and they confirm DNA methylation as a global repressor of gene expression. The scenario has been modeled using an artificial construct that contained a DNA sequence capable of excluding methylation locally during early development (Siegfried et al. 1999). When this sequence was present, the reporter gene stayed unmethylated during development, and widespread expression occurred. Deletion of the element in situ in the early embryo led to methylation of the reporter gene and concomitant silencing in several adult tissues.

A subtle potential role for loss of methylation at a specific gene has been reported for the rat tyrosine aminotransferase gene (Thomassin et al. 2001). When a methylated form of this gene is induced by glucocorticoids, delayed demethylation occurs at specific sites in an enhancer and additional DNA-associated factors are subsequently recruited. Demethylation /whether active or passive is not known) persists after the wave of TAT 
expression has subsided, and reinduction of the silent gene by a further hormone treatment is significantly stronger as a result. This system provides a model for a DNA methylation-mediated memory of the first hormone induction (Kress et al. 2001). Its significance is somewhat less certain in normal development, however, because demethylation of these sites occurs before the gene becomes hormone-inducible.

There is suggestive evidence that programmed rearrangement of the immunoglobulin genes during B-cell development may involve DNA methylation (Mostoslavsky et al. 1998). Demethylation of one of the two parentally derived alleles of the kappa light chain gene is observed in small pre-B cells, and there is evidence that this early loss of methylation predisposes the affected allele to rearrangement. By precluding rearrangement of one allele, differential DNA methylation may help to explain allelic exclusion at the kappa chain locus. It is not certain whether transcriptional regulation per se plays a role, although the process is dependent on the intronic and 3' kappa gene enhancers.

\section{Loss of genome integrity as a consequence of DNA methylation loss?}

Early studies with the DNA-methylation inhibitor 5-azacytidine revealed bizarre chromosomal rearrangements in treated cultured cells (Viegas-Pequignot and Dutrillaux 1976). Although these findings might be attributed to the effects of reduced DNA methylation, they could also be a result of the chemical reactivity of the incorporated base analog, in particular, its ability to cross-link proteins to DNA (Juttermann et al. 1994). The former possibility is supported somewhat by the finding that mitogen-stimulated lymphocytes from patients with mutations in DNMT3B show very similar chromosome rearrangements, involving coalescence of centromeric regions that contain methylation-deficient repetitive sequences (Jeanpierre et al. 1993; Xu et al. 1999). Oddly, the rearrangements are not seen in cells of the patients, despite similar hypomethylation of these regions. It seems that loss of genomic integrity is not an obligatory consequence of hypomethylation of juxtacentromeric repeat elements.

At a finer level, two laboratories have examined the effects of greatly reduced DNA methylation levels on mutation rates in mouse embryonic stem cells, with somewhat differing results. In one study, the mutation rate at two endogenous loci was found to have increased $\sim 10$-fold compared to the same loci in wild-type cells (Chen et al. 1998), suggesting that lack of methylation predisposed to aberrant recombination events. A second study examined transgenes of exogenous origin using a selection system to detect mutations (Chan et al. 2001). This allowed screening of large numbers of mutations at two independent loci, but neither point mutations nor genomic rearrangements were increased under conditions of limiting DNA methylation. In fact, mutations appeared to be suppressed by genomic hypomethylation. These inconsistencies raise questions about the pro- posed relationship between genome integrity and DNA methylation that will need to be addressed by further research.

\section{Developmental memory: DNA methylation and Polycomb/trithorax complexes as interchangeable systems}

The foregoing discussion has highlighted features of the DNA methylation system in mammals that resemble another established system of cellular memory: Pc-G/ trx. The final section of the review will compare the two systems. The credentials of Pc-G/trx protein complexes as an epigenetic system in development are compelling (Paro et al. 1998; Pirrotta 1999; Francis and Kingston 2001). This multiprotein assembly is targeted to specific regions of the genome where it effectively freezes the embryonic expression status of a gene, be it active or inactive, and propagates that state stably through development. Elegant experiments with model gene constructs have shown that brief activation (or inactivation) of a promoter during early Drosophila development leads to stable activity (or inactivity) thereafter (Cavalli and Paro 1998, 1999; Poux et al. 2001). Attempts to alter expression at most other stages of development were unsuccessful, indicating that there is a window of time during which transcription patterns can be committed to developmental memory. The Pc-G/trx system is reactive rather than proactive, as the setting up of segment-specific patterns of active genes is not disrupted by mutations in Pc-G group genes. Only the capacity to sustain the patterns is lost in the mutants. This ability to copy and propagate the expression patterns without influencing or perturbing them makes this a subtle and flexible memory system. Little is known, however, about the mechanisms responsible for the heritability of Pc-G/trx.

What do Pc-G/trx and DNA methylation in mammals have in common? First, both systems are able to repress transcription in a heritable manner. Second, both appear to be reactive in that they lock in expression states that they played no part in setting up (e.g., DNA methylation in viral genome silencing and CpG-island methylation on the X chromosome). Third, both are activated primarily during a discrete window of time in early development. Thus, like Pc-G/trx, DNA methylation has the properties of a developmental memory.

What is memorized by DNA methylation? Arguably, its major role is to stably demarkate by its absence a set of embryonically active promoters, namely, CpG islands, so that they remain potentially active throughout development and adulthood. At the same time, regions devoid of promoter activity in the embryo become methylated and carry this repressive influence with them through development. The degree of repression may be weak or strong depending on the density of methylation (Boyes and Bird 1992; Hsieh 1994). Thus, CpG islands that are silenced by other mechanisms during embryogenesis would acquire dense methylation leading to irreversible silencing. When, however, the density of methylated CpGs is low, as it is in most of the genome, 
repression is likely to be weak and may be overcome by the presence of strong activators. Weak repression of tissue-specific genes (e.g., $\beta$-globin) that are embedded in regions of low-density methylation may contribute to their silence in inappropriate tissues.

It is proposed here that DNA methylation and Pc-G/ trx are alternative systems of cellular memory that are interchangeable over evolutionary time. In C. elegans and Drosophila, for example, Pc-G group proteins (Birchler et al. 2000) have been implicated in silencing of repetitive-element transcription in somatic cells, whereas DNA methylation may play this role in mammals (Yoder et al. 1997). The involvement of DNA methylation in genome defence may, therefore, be to memorize the silent state of elements imposed by primary genome defence systems. The most striking evidence for interchangeability is the finding that $\mathrm{X}$ chromosome inactivation in extraembryonic tissues of the mouse depends on the polycomb group protein Eed. Loss of the eed gene leads to reactivation of the inactive $\mathrm{X}$ in extraembryonic tissue, but has no effect in somatic cell types (Wang et al. 2001). In contrast, Dnmt1 mutations reactivate the inactive $\mathrm{X}$ of the embryo proper, but not the extraembryonic inactive $X$ (Sado et al. 2000). The finding that certain CpG islands on the inactive X chromosome are methylated in somatic cells but not in extraembryonic tissues (Iida et al. 1994) fits with the view that methylation replaces Pc-G in somatic tissues. Therefore, even within a single species, it appears that different tissues employ Pc-G/trx and DNA methylation interchangeably. From an evolutionary perspective, it is possible that varying degrees of functional substitution by Pc-G (or vice versa) can explain the dramatic differences between DNA methylation levels across animal species.

\section{Concluding remarks}

Our understanding of the relationship between DNA methylation and transcriptional control is growing fast, but is still far from complete. Ongoing biochemical analysis of the growing number of components of the DNA methylation system (and their partners), coupled with genetic approaches, will strengthen the links between DNA methylation and mainstream transcriptional mechanisms. Regulation of gene expression is complex (Lemon and Tjian 2000), and the emerging evidence hints that the roles of DNA methylation will be too. It may be unrealistic to expect that any unified theory will encompass all the biological consequences of DNA methylation.

Least understood are the mechanisms by which methylation patterns are generated. Following consideration of the criteria for attracting and repelling DNA methylation, this review has entertained the possibility that a primary function of de novo DNA methylation is to memorize patterns of embryonic gene activity, creating CpG islands that are competent for transcription throughout development, or their antithesis, regions that are methylated and transcriptionally incompetent. The idea depends on evidence that methylation does not intervene to silence genes that are actively transcribed, but only affects genes that have already been shut down by other means. There is reason to believe that transcriptional activity may somehow imprint the methylationfree status of CpG islands. The involvement of DNA methylation in inactivation of transposable elements could likewise be due to its capacity for stabilizing the transcriptional shutdown organized by other systems. Parallels between these emerging attributes of DNA methylation and the Pc-G system in Drosophila suggest that both are mechanisms for sensing and propagating cellular memory.

\section{Acknowledgments}

I am grateful to Eric Selker, Bernard Ramsahoye, Helle Jørgensen, Brian Hendrich, and Catherine Millar for comments on the manuscript. Research by A.B. is supported by The Wellcome Trust.

\section{References}

Amir, R.E., Van den Veyver, I.B., Wan, M., Tran, C.Q., Francke, U., and Zoghbi, H.Y. 1999. Rett syndrome is caused by mutations in X-linked MECP2, encoding methyl-CpG-binding protein 2. Nat. Genet. 23: 185-188.

Antequera, F. and Bird, A. 1993. Number of CpG islands and genes in human and mouse. Proc. Natl. Acad. Sci. 90: $11995-11999$.

- 1999. CpG islands as genomic footprints of promoters that are associated with replication origins. Curr. Biol. 9: R661-R667.

Antequera, F., Boyes, J., and Bird, A. 1990. High levels of de novo methylation and altered chromatin structure at $\mathrm{CpG}$ islands in cell lines. Cell 62: 503-514.

Bachman, K.E., Rountree, M.R., and Baylin, S.B. 2001. Dnmt3a and Dnmt3b are transcriptional repressors that exhibit unique localization properties to heterochromatin. J. Biol. Chem. 276: 32282-32287.

Bannister, A.J., Zegerman, P., Partridge, J.F., Miska, E.A., Thomas, J.O., Allshire, R.C., and Kouzarides, T. 2001. Selective recognition of methylated lysine 9 on histone $\mathrm{H} 3$ by the HP1 chromo domain. Nature 410: 120-124.

Baylin, S.B. and Herman, J.G. 2000. DNA hypermethylation in tumorigenesis: Epigenetics joins genetics. Trends Genet. 16: $168-174$.

Beard, C., Li, E., and Jaenisch, R. 1995. Loss of methylation activates Xist in somatic but not in embryonic cells. Genes \& Dev. 9: 2325-2334.

Bell, A.C. and Felsenfeld, G. 2000. Methylation of a CTCF-dependent boundary controls imprinted expression of the Igf2 gene. Nature 405: 482-485.

Bell, A.C., West, A.G., and Felsenfeld, G. 1999. The protein CTCF is required for the enhancer blocking activity of vertebrate insulators. Cell 98: 387-396.

Bender, J. 2001. A vicious cycle. RNA silencing and DNA methylation in plants. Cell 106: $129-132$.

Bestor, T.H. 1992. Activation of mammalian DNA methyltransferase by cleavage of a $\mathrm{Zn}$ binding regulatory domain. EMBO I. 11: 2611-2617.

- 2000. The DNA methyltransferases of mammals. Hum. Mol. Genet. 9: 2395-2402.

Bestor, T. and Tycko, B. 1996. Creation of genomic methylation 
patterns. Nat. Genet. 12: 363-367.

Bhattacharya, S.K., Ramchandani, S., Cervoni, N., and Szyf, M. 1999. A mammalian protein with specific demethylase activity for mCpG DNA. Nature 397: 579-583.

Birchler, J.A., Bhadra, M.P., and Bhadra, U. 2000. Making noise about silence: Repression of repeated genes in animals. Curr. Opin. Genet. Dev. 10: 211-216.

Bird, A.P. 1986. CpG-rich islands and the function of DNA methylation. Nature 321: 209-213.

- 1987. CpG islands as gene markers in the vertebrate nucleus. Trends Genet. 3: 342-347.

- 1995. Gene number, noise reduction and biological complexity. Trends Genet. 11: 94-100.

1997. Does DNA methylation control transposition of selfish elements in the germline. Trends Genet. 13: 469-470.

Bird, A. and Wolffe, A.P. 1999. Methylation-induced repression-Belts, braces and chromatin. Cell 99: 451-454.

Bird, A.P., Taggart, M.H., and Smith, B.A. 1979. Methylated and unmethylated DNA compartments in the sea urchin genome. Cell 17: 889-901.

Bird, A.P., Taggart, M.H., Nicholls, R.D., and Higgs, D.R. 1987. Non-methylated CpG-rich islands at the human $\alpha$-globin locus: Implications for evolution of the $\alpha$-globin pseudogene. EMBO J. 6: 999-1004.

Birger, Y., Shemer, R., Perk, J., and Razin, A. 1999. The imprinting box of the mouse Igf2r gene. Nature 397: 84-88.

Bourc'his, D., Le Bourhis, D., Patin, D., Niveleau, A., Comizzoli, P., Renard, J., and Viegas-Pequignot, E. 2001. Delayed and incomplete reprogramming of chromosome methylation patterns in bovine cloned embryos. Curr. Biol. 11: 1542-1546.

Boyes, J. and Bird, A. 1992. Repression of genes by DNA methylation depends on CpG density and promoter strength: Evidence for involvement of a methyl-CpG binding protein. EMBO J. 11: 327-333.

Brandeis, M., Frank, D., Keshet, I., Siegried, Z., Mendelsohn, M., Nemes, A., Temper, V., Razin, A., and Cedar, H. 1994. Sp1 elements protect a $\mathrm{CpG}$ island from de novo methylation. Nature 371: 435-438.

Cavalli, G. and Paro, R. 1998. The Drosophila Fab-7 chromosomal element conveys epigenetic inheritance during mitosis and meiosis. Cell 93: 505-518.

- 1999. Epigenetic inheritance of active chromatin after removal of the main transactivator. Science 286: 955-958.

Chan, M.F., van Amerongen, R., Nijiar, T., Cuppen, E., Jones, P.A., and Laird, P.W. 2001. Reduced rates of gene loss, gene silencing, and gene mutation in dnmt1-deficient embryonic stem cells. Mol. Cell. Biol. 21: 7587-7600.

Chen, R.Z., Pettersson, U., Beard, C., Jackson-Grusby, L., and Jaenisch, R. 1998. DNA hypomethylation leads to elevated mutation rates. Nature 395: 89-93.

Chen, R.Z., Akbarian, S., Tudor, M., and Jaenisch, R. 2001. Deficiency of methyl-CpG binding protein-2 in CNS neurons results in a Rett-like phenotype in mice. Nat. Genet. 27: 327-331.

Chu, W.M., Ballard, R., Carpick, B.W., Williams, B.R., and Schmid, C.W. 1998. Potential Alu function: Regulation of the activity of double-stranded RNA-activated kinase PKR. Mol. Cell. Biol. 18: 58-68.

Cogoni, C., Irelan, J.T., Schumacher, M., Schmidhauser, T.J., Selker, E.U., and Macino, G. 1996. Transgene silencing of the al-1 gene in vegetative cells of Neurospora is mediated by a cytoplasmic effector and does not depend on DNA-DNA interactions or DNA methylation. EMBO J. 15: 3153-3163.

Colot, V. and Rossignol, J.L. 1999. Eukaryotic DNA methylation as an evolutionary device. BioEssays 21: 402-411.
Colot, V., Maloisel, I.L., and Rossignol, J.-L. 1996. Interchromosomal transfer of epigenetic states in Ascobolus: Transfer of DNA methylation is mechanistically related to homologous recombination. Cell 86: 855-864.

Cosma, M.P., Tanaka, T., and Nasmyth, K. 1999. Ordered recruitment of transcription and chromatin remodeling factors to a cell cycle- and developmentally-regulated promoter. Cell 97: 299-311.

Costello, J.F. and Plass, C. 2001. Methylation matters. J. Med. Genet. 38: 285-303.

Cross, S.H., Meehan, R.R., Nan, X., and Bird, A. 1997. A component of the transcriptional repressor MeCP1 is related to mammalian DNA methyltransferase and trithorax-like protein. Nat. Genet. 16: 256-259.

Cuadrado, M., Sacristan, M., and Antequera, F. 2001. Speciesspecific organization of CpG island promoters at mammalian homologous genes. EMBO Rep. 2: 586-592.

Daniels, R., Lowell, S., Bolton, V., and Monk, M. 1997. Transcription of tissue-specific genes in human preimplantation embryos. Hum. Reprod. 12: 2251-2256.

Delgado, S., Gomez, M., Bird, A., and Antequera, F. 1998. Initiation of DNA replication at CpG islands in mammalian chromosomes. EMBO J. 17: 2426-2435.

Dennis, K., Fan, T., Geiman, T., Yan, Q., and Muegge, K. 2001. Lsh, a member of the SNF2 family, is required for genomewide methylation. Genes \& Dev. 15: 2940-2944.

De Smet, C., De Backer, O., Faraoni, I., Lurquin, C., Brasseur, F., and Boon, T. 1996. The activation of human gene MAGE-1 in tumor cells is correlated with genome-wide demethylation. Proc. Natl. Acad. Sci. 93: 7149-7153.

De Smet, C., Lurquin, C., Lethe, B., Martelange, V., and Boon, T. 1999. DNA methylation is the primary silencing mechanism for a set of germ line- and tumor-specific genes with a CpGrich promoter. Mol. Cell. Biol. 11: 7327-7335.

Ehrlich, M. 1982. Amount and distribution of 5-methycytosine in human DNA from different types of tissues or cells. Nucleic Acids Res. 10: 2709-2721.

Ferguson-Smith, A.C. and Surani, M.A. 2001. Imprinting and the epigenetic asymmetry between parental genomes. Science 293: 1086-1089.

Finnegan, E.J., Peacock, W.J., and Dennis, E.S. 2000. DNA methylation, a key regulator of plant development and other processes. Curr. Opin. Genet. Dev. 10: 217-223.

Flatau, E., Gonzales, F.A., Michalowsky, L.A., and Jones, P.A. 1984. DNA methylation in 5-Aza-2'-deoxycytidine-resistant variants of C3H 10T1/2 C18 cells. Mol. Cell. Biol. 4: 20982102.

Francis, N.J. and Kingston, R.E. 2001. Mechanisms of transcriptional memory. Nat. Rev. Mol. Cell. Biol. 2: 409-421.

Fuks, F., Burgers, W.A., Brehm, A., Hughes-Davies, L., and Kouzarides, T. 2000. DNA methyltransferase Dnmt1 associates with histone deacetylase activity. Nat. Genet. 24: 8891.

Fuks, F., Burgers, W.A., Godin, N., Kasai, M., and Kouzarides, T. 2001. Dnmt3a binds deacetylases and is recruited by a sequence-specific repressor to silence transcription. EMBO $\mathrm{J}$. 20: $2536-2544$.

Garrick, D., Fiering, S., Martin, D.I., and Whitelaw, E. 1998. Repeat-induced gene silencing in mammals. Nat. Genet. 18: $56-59$.

Gautsch, J.W. and Wilson, M.C. 1983. Delayed de novo methylation in teratocarcinoma cells suggests additional tissuespecific mechanisms for controlling gene expression. Nature 301: 32-37.

Gibbons, R.J., McDowell, T.L., Raman, S., O'Rourke, D.M., Garrick, D., Ayyub, H., and Higgs, D.R. 2000. Mutations in 
ATRX, encoding a SWI/SNF-like protein, cause diverse changes in the pattern of DNA methylation. Nat. Genet. 24: $368-371$.

Gowher, H. and Jeltsch, A. 2001. Enzymatic properties of recombinant Dnmt3a DNA methyltransferase from mouse: The enzyme modifies DNA in a non-processive manner and also methylates non-CpG [correction of non-CpA] sites. J. Mol. Biol. 309: 1201-1208.

Gowher, H., Leismann, O., and Jeltsch, A. 2000. DNA of Drosophila melanogaster contains 5-methylcytosine. EMBO J. 19: 6918-6923.

Graves, J.A. 1982. 5-Azacytidine-induced re-expression of alleles on the inactive $\mathrm{X}$ chromosome in a hybrid mouse cell line. Exp. Cell Res. 141: 99-105.

Gurdon, J.B. 1999. Genetic reprogramming following nuclear transplantation in Amphibia. Semin. Cell Dev. Biol. 10: 239-243.

Guy, J., Hendrich, B., Holmes, M., Martin, J.E., and Bird, A. 2001. A mouse Mecp2-null mutation causes neurological symptoms that mimic Rett syndrome. Nat. Genet. (in press).

Hansen, R.S., Stoger, R., Wijmenga, C., Stanek, A.M., Canfield, T.K., Luo, P., Matarazzo, M.R., D’Esposito, M., Feil, R., Gimelli, G., et al. 2000. Escape from gene silencing in ICF syndrome: Evidence for advanced replication time as a major determinant. Hum. Mol. Genet. 9: 2575-2587.

Hark, A.T., Schoenherr, C.J., Katz, D.J., Ingram, R.S., Levorse, J.M., and Tilghman, S.M. 2000. CTCF mediates methylation-sensitive enhancer-blocking activity at the H19/Igf2 locus. Nature 405: 486-489.

Harris, M. 1982. Induction of thymidine kinase in enzyme-deficient Chinese hamster cells. Cell 29: 483-492.

Hendrich, B. and Bird, A. 1998. Identification and characterization of a family of mammalian methyl-CpG binding proteins. Mol. Cell. Biol. 18: 6538-6547.

Hendrich, B., Guy, J., Ramsahoye, B., Wilson, V.A., and Bird, A. 2001. Closely related proteins Mbd2 and Mbd3 play distinctive but interacting roles in mouse development. Genes \& Dev. 15: 1613-1618.

Hertz, J.M., Schell, G., and Doerfler, W. 1999. Factors affecting de novo methylation of foreign DNA in mouse embryonic stem cells. J. Biol. Chem. 274: 24232-24240.

Holliday, R. and Pugh, J.E. 1975. DNA modification mechanisms and gene activity during development. Science 186: $226-232$.

Holmgren, C., Kanduri, C., Dell, G., Ward, A., Mukhopadhya, R., Kanduri, M., Lobanenkov, V., and Ohlsson, R. 2001. CpG methylation regulates the Igf2/H19 insulator. Curr. Biol. 11: 1128-1130.

Howell, C.Y., Bestor, T.H., Ding, F., Latham, K.E., Mertineit, C., Trasler, J.M., and Chaillet, J.R. 2001. Genomic imprinting disrupted by a maternal effect mutation in the Dnmtl gene. Cell 104: 829-838.

Hsieh, C.-L. 1994. Dependence of transcriptional repression on CpG methylation density. Mol. Cell. Biol. 14: 5487-5494.

- 1999a. Evidence that protein binding specifies sites of DNA demethylation. Mol. Cell. Biol. 19: 46-56.

- $1999 \mathrm{~b}$. In vivo activity of murine de novo methyltransferases, Dnmt3a and Dnmt3b. Mol. Cell. Biol. 19: $8211-8218$.

- 2000. Dynamics of DNA methylation pattern. Curr. Opin. Genet. Dev. 10: 224-228.

Hung, M.S., Karthikeyan, N., Huang, B., Koo, H.C., Kiger, J., and Shen, C.J. 1999. Drosophila proteins related to vertebrate DNA (5-cytosine) methyltransferases. Proc. Natl. Acad. Sci. 96: 11940-11945.

Iida, T., Nakahori, Y., Tsutsumi, O., Taketani, Y., and Nak- agome, Y. 1994. The CpG island of the FMR-1 gene is methylated differently among embryonic tissues: Implication for prenatal diagnosis. Hum. Reprod. 9: 1471-1473.

Issa, J.P. 2000. CpG-island methylation in aging and cancer. Curr. Top. Microbiol. Immunol. 249: 101-118.

Jackson-Grusby, L., Beard, C., Possemat, R., Tudor, M., Fambrough, D., Csankovszki, G., Dausman, J., Lee, P., Wilson, C., Lander, E., et al. 2001. Loss of genomic methylation causes p53-dependent apoptosis and epigenetic deregulation. Nat. Genet. 27: 31-39.

Jaenisch, R. 1997. DNA methylation and imprinting: Why bother? Trends Genet. 13: 323-329.

Jaenisch, R., Harbers, K., Jahner, D., Stewart, C., and Stuhlmann, H. 1982. DNA methylation, retroviruses, and embryogenesis. J. Cell Biochem. 20: 331-336.

Jaenisch, R., Schnieke, A., and Harbers, K. 1985. Treatment of mice with 5-azacytidine efficiently activates silent retroviral genomes in different tissues. Proc. Natl. Acad. Sci. 82: 14511455.

Jeanpierre, M., Turleau, C., Aurias, A., Prieur, M., Ledeist, F., Fischer, A., and Viegas-Pequignot, E. 1993. An embryoniclike methylation pattern of classical satellite DNA is observed in ICF syndrome. Hum. Mol. Genet. 2: 731-735.

Jeddeloh, J.A., Stokes, T.L., and Richards, E.J. 1999. Maintenance of genomic methylation requires a SW12/SNF2-like protein. Nat. Genet. 22: 94-97.

Jenuwein, T. and Allis, C.D. 2001. Translating the histone code. Science 293: 1074-1080.

Jones, P.A. and Takai, D. 2001. The role of DNA methylation in mammalian epigenetics. Science 293: 1068-1070.

Jones, P.A. and Taylor, S.M. 1980. Cellular differentiation, cytidine analogues and DNA methylation. Cell 20: 85-93.

Jones, P.A., Wolkowicz, M.J., Rideout, W.M.I., Gonzales, F.A., Marziasz, C.M., Coetzee, G.A., and Tapscott, S.J. 1990. De novo methylation of the MyoD1 CpG island during the establishment of immortal cell lines. Proc. Natl. Acad. Sci. 87: 6117-6121.

Jost, J.P., Fremont, M., Siegmann, M., and Hofsteenge, J. 1997. The RNA moiety of chick embryo 5-methylcytosine-DNA glycosylase targets DNA demethylation. Nucleic Acids Res. 25: 4545-4550.

Jost, J.P., Siegmann, M., Thiry, S., Jost, Y.C., Benjamin, D., and Schwarz, S. 1999. A re-investigation of the ribonuclease sensitivity of a DNA demethylation reaction in chicken embryo and G8 mouse myoblasts. FEBS Lett. 449: 251-254.

Juttermann, R., Li, E., and Jaenisch, R. 1994. Toxicity of 5-aza2 -deoxycytidine to mammalian cells is mediated primarily by covalent trapping of DNA methyltransferase rather than DNA demethylation. Proc. Natl. Acad. Sci. 91: 11797-11801.

Kafri, T., Ariel, M., Brandeis, M., Shemer, R., Urven, L., McCarrey, J., Cedar, H., and Razin, A. 1992. Developmental pattern of gene-specific DNA methylation in the mouse embryo and germ line. Genes \& Dev. 6: 705-714.

Kang, Y.K., Koo, D.B., Park, J.S., Choi, Y.H., Chung, A.S., Lee, K.K., and Han, Y.M. 2001a. Aberrant methylation of donor genome in cloned bovine embryos. Nat. Genet. 28: 173-177.

Kang, Y.K., Koo, D.B., Park, J.S., Choi, Y.H., Kim, H.N., Chang, W.K., Lee, K.K., and Han, Y.M. 2001b. Typical demethylation events in cloned pig embryos. Clues on species-specific differences in epigenetic reprogramming of cloned donor genome. J. Biol. Chem. 276: 39980-39984.

Kass, S.U., Landsberger, N., and Wolffe, A.P. 1997a. DNA methylation directs a time-dependent repression of transcription initiation. Curr. Biol. 7: 157-165.

Kass, S.U., Pruss, D., and Wolffe, A.P. 1997b. How does DNA 
methylation repress transcription? Trends Genet. 13: 444 449.

Keohane, A.M., O'Neill, L.P., Belyaev, N.D., Lavender, J.S., and Turner, B.M. 1996. X-inactivation and histone H4 acetylation in embryonic stem cells. Dev. Biol. 180: 618-630.

Kondo, T., Bobek, M.P., Kuick, R., Lamb, B., Zhu, X., Narayan, A., Bourc'his, D., Viegas-Pequignot, E., Ehrlich, M., et al. 2000. Whole-genome methylation scan in ICF syndrome: Hypomethylation of non-satellite DNA repeats D4Z4 and NBL2. Hum. Mol. Genet. 9: 597-604.

Kress, C., Thomassin, H., and Grange, T. 2001. Local DNA demethylation in vertebrates: How could it be performed and targeted? FEBS Lett. 494: 135-140.

Laayoun, A. and Smith, S.S. 1995. Methylation of slipped duplexes, snapbacks and cruciforms by human DNA/cytosine5)methyltransferase. Nucleic Acids Res. 23: 1584-1589.

Lander, E.S., Linton, L.M., Birren, B., Nusbaum, C., Zody, M.C., Baldwin, J., Devon, K., Dewar, K., Doyle, M., FitzHugh, W., et al. 2001. Initial sequencing and analysis of the human genome. Nature 409: 860-921.

Lemon, B. and Tjian, R. 2000. Orchestrated response: A symphony of transcription factors for gene control. Genes \& Dev. 14: 2551-2569.

Li, E., Bestor, T.H., and Jaenisch, R. 1992. Targeted mutation of the DNA methyltransferase gene results in embryonic lethality. Cell 69: 915-926.

Li, E., Beard, C., and Jaenisch, R. 1993. Role for DNA methylation in genomic imprinting. Nature 366: 362-365.

Lin, I.G., Tomzynski, T.J., Ou, Q., and Hsieh, C.L. 2000. Modulation of DNA binding protein affinity directly affects target site demethylation. Mol. Cell. Biol. 20: 2343-2349.

Liu, W.M., Maraia, R.J., Rubin, C.M., and Schmid, C.W. 1994. Alu transcrips: Cytoplasmic localisation and regulation by DNA methylation. Nucleic Acids Res. 22: 1087-1095.

Liu, W.M., Chu, W.M., Choudary, P.V., and Schmid, C.W. 1995. Cell stress and translational inhibitors transiently increase the abundance of mammalian SINE transcripts. Nucleic Acids Res. 23: 1758-1765.

Lock, L.F., Takagi, N., and Martin, G.R. 1987. Methylation of the Hprt gene on the inactive $\mathrm{X}$ occurs after chromosome inactivation. Cell 48: 39-46.

Lorincz, M.C., Schubeler, D., Goeke, S.C., Walters, M., Groudine, M., and Martin, D.I.K. 2000. Dynamic analysis of proviral induction and de novo methylation: Implications for a histone deacetylase-independent, methylation density-dependent mechanism of transcriptional repression. Mol. Cell. Biol. 20: 842-850.

Lyko, F., Ramsahoye, B.H., Kashevsky, H., Tudor, M., Mastrangelo, M.-A., Orr-Weaver, T.L., and Jaenisch, R. 1999. Mammalian (cytosine-5) methyltransferases cause genomic DNA methylation and lethality in Drosophila. Nat. Genet. 23: 363-366.

Lyko, F., Ramsahoye, B.H., and Jaenisch, R. 2000. DNA methylation in Drosophila melanogaster. Nature 408: 538-540.

Lyle, R., Watanabe, D., te Vruchte, D., Lerchner, W., Smrzka, O.W., Wutz, A., Schageman, J., Hahner, L., Davies, C., and Barlow, D.P. 2000. The imprinted antisense RNA at the Igf2r locus overlaps but does not imprint Mas1. Nat. Genet. 25: 19-21.

MacLeod, D., Charlton, J., Mullins, J., and Bird, A.P. 1994. Sp1 sites in the mouse aprt gene promoter are required to prevent methylation of the CpG island. Genes \& Dev. 8: 2282-2292.

MacLeod, D., Ali, R.R., and Bird, A.P. 1998. An alternative promoter in the mouse major histocompatibility cmplex class II I-Ab gene: Implications for the origin of CpG islands. Mol. Cell. Biol. 18: 4433-4443.
MacLeod, D., Clark, V., and Bird, A. 1999. Absence of genomewide changes in DNA methylation during development of the zebrafish (Danio rerio). Nat. Genet. 23: 139-140.

Malik, H.S., Burke, W.D., and Eickbush, T.H. 1999. The age and evolution of non-LTR retrotransposable elements. Mol. Biol. Evol. 16: 793-805.

Martienssen, R.A. and Colot, V. 2001. DNA methylation and epigenetic inheritance in plants and filamentous fungi. Science 293: 1070-1074.

Matzke, M., Matzke, A.J., and Kooter, J.M. 2001. RNA: Guiding gene silencing. Science 293: 1080-1083.

Mayer, W., Niveleau, A., Walter, J., Fundele, R., and Haaf, T. 2000. Demethylation of the zygotic paternal genome. $\mathrm{Na}$ ture 403: 501-502.

McKeon, C., Ohkubo, H., Pastan, I., and de Crombrugghe, B. 1982. Unusual methylation pattern of the $\alpha 2(1)$ collagen gene. Cell 29: 203-210.

Miao, V.P., Freitag, M., and Selker, E.U. 2000. Short TpA-rich segments of the $\zeta-\eta$ region induce DNA methylation in Neurospora crassa. J. Mol. Biol. 300: 249-273.

Miniou, P., Jeanpierre, M., Blanquet, V., Sibella, V., Bonneau, D., Herbelin, C., Fischer, A., Niveleau, A., and ViegasPequignot, E. 1994. Abnormal methylation pattern in constitutive and facultative (X inactive chromosome) heterochromatin of ICF patients. Hum. Mol. Genet. 3: 2093-2102.

Mohandas, T., Sparkes, R.S., and Shapiro, L.J. 1981a. Reactivation of an inactive human $\mathrm{X}$ chromosome: Evidence for $\mathrm{X}$ inactivation by DNA methylation. Science 211: 393-396.

. 1981b. Reactivation of an inactive human X-chromosome: Evidence for X-inactivation by DNA methylation. Science 211: 393-396.

Monk, M., Boubelik, M., and Lehnert, S. 1987. Temporal and regional changes in DNA methylation in the embryonic, extraembryonic and germ cell lineages during mouse embryo development. Development 99: 371-382.

Moore, T. and Haig, D. 1991. Genomic imprinting in mammalian development: A parental tug-of-war. TIG 7: 1-4.

Mostoslavsky, R., Singh, N., Kirillov, A., Pelanda, R., Cedar, H., Chess, A., and Bergman, Y. 1998. $\kappa$ chain monoallelic demethylation and the establishment of allelic exclusion. Genes \& Dev. 12: 1801-1811.

Mummaneni, P., Bishop, P.L., and Turker, M.S. 1993. A cisacting element accounts for a conserved methylation pattern upstream of the mouse adenine phosphoribosyltransferase gene. J. Biol. Chem. 268: 552-558.

Mummaneni, P., Yates, P., Simpson, J., Rose, J., and Turker, M.S. 1998. The primary function of a redundant Sp1 binding site in the mouse aprt gene promoter is to block epigenetic gene inactivation. Nucleic Acids Res. 26: 5163-5169.

Nakayama, J., Rice, J.C., Strahl, B.D., Allis, C.D., and Grewal, S.I. 2001. Role of histone H3 lysine 9 methylation in epigenetic control of heterochromatin assembly. Science 292: $110-113$.

Nan, X., Meehan, R.R., and Bird, A. 1993. Dissection of the methyl-CpG binding domain from the chromosomal protein MeCP2. Nucleic Acids Res. 21: 4886-4892.

Nan, X., Campoy, J., and Bird, A. 1997. MeCP2 is a transcriptional repressor with abundant binding sites in genomic chromatin. Cell 88: 471-481.

Niwa, O., Yokota, Y., Ishida, H., and Sugahara, T. 1983. Independent mechanisms involved in suppression of the Moloney leukaemia virus genome during differentiation of murine teratocarinoma cells. Cell 32: 1105-1113.

Noma, K., Allis, C.D., and Grewal, S.I. 2001. Transitions in distinct histone $\mathrm{H} 3$ methylation patterns at the heterochromatin domain boundaries. Science 293: 1150-1155. 
Okano, M., Xie, S., and Li, E. 1998a. Cloning and characterization of a family of novel mammalian DNA (cytosine-5) methyltransferases. Nat. Genet. 19: 219-220.

1998b. Dnmt2 is not required for de novo and maintenance methylation of viral DNA in embryonic stem cells. Nucleic Acids Res. 26: 2536-2540.

Okano, M., Bell, D.W., Haber, D.A., and Li, E. 1999. DNA methyltransferases Dnmt3a and Dnmt3b are essential for de novo methylation and mammalian development. Cell 99: 247-257.

Oswald, J., Engemann, S., Lane, N., Mayer, W., Olek, A., Fundele, R., Dean, W., Reik, W., and Walter, J. 2000. Active demethylation of the paternal genome in the mouse zygote. Curr. Biol. 10: 475-478.

Pannell, D., Osborne, C.S., Yao, S., Sukonnik, T., Pasceri, P. Karaiskakis, A., Okano, M., Li, E., Lipshitz, H.D., and Ellis, J. 2000. Retrovirus vector silencing is de novo methylase independent and marked by a repressive histone code. EMBO J. 19: 5884-5894.

Panning, B. and Jaenisch, R. 1996. DNA hypomethylation can activate Xist expression and silence X-linked genes. Genes \& Dev. 10: 1991-2002.

Paro, R., Strutt, H., and Cavalli, G. 1998. Heritable chromatin states induced by the Polycomb and trithorax group genes. Novartis Found. Symp. 214: 51-61.

Pfeifer, G.P., Steigerwald, S.D., Hansen, R.S., Gartler, S.M., and Riggs, A.D. 1990. Polymerase chain reaction-aided genomic sequencing of an X chromosome-linked CpG island: Methylation patterns suggest clonal inheritance, CpG site autonomy, and an explanation of activity state stability. Proc. Nat. Acad. Sci. 87: 8252-8256.

Pirrotta, V. 1999. Polycomb silencing and the maintenance of stable chromatin states. Results Probl. Cell. Differ. 25: 205228.

Pollack, Y., Stein, R., Razin, A., and Cedar, H. 1980. Methylation of foreign DNA sequences in eukaryotic cells. Proc. Natl. Acad. Sci. 77: 6463-6467.

Poux, S., McCabe, D., and Pirrotta, V. 2001. Recruitment of components of Polycomb Group chromatin complexes in Drosophila. Development 128: 75-85.

Pradhan, S., Bacolla, A., Wells, R.D., and Roberts, R.J. 1999. Recombinant human DNA (cytosine-5) methyltransferase. I. Expression, purification, and comparison of de novo and maintenance methylation. J. Biol. Chem. 274: 33002-33010.

Prokhortchouk, A., Hendrich, B., Jorgensen, H., Ruzov, A., Wilm, M., Georgiev, G., Bird, A., and Prokhortchouk, E. 2001. The p120 catenin partner Kaiso is a DNA methylationdependent transcriptional repressor. Genes \& Dev. 15: 16131618.

Ramchandani, S., Bhattacharya, S.K., Cervoni, N., and Szyf, M. 1999. DNA methylation is a reversible biological signal. Proc. Nat1. Acad. Sci. 96: 6107-6112.

Ramsahoye, B.H., Biniszkiewicz, D., Lyko, F., Clark, V., Bird, A.P., and Jaenisch, R. 2000. Non-CpG methylation is prevalent in embryonic stem cells and may be mediated by DNA methyltransferase 3a. Proc. Nat1. Acad. Sci. 97: 5237-5242.

Reik, W. and Walter, J. 2001. Evolution of imprinting mechanisms: The battle of the sexes begins in the zygote. Nat. Genet. 27: 255-256.

Reik, W., Dean, W., and Walter, J. 2001. Epigenetic reprogramming in mammalian development. Science 293: 1089-1093.

Rhee, I., Jair, K.W., Yen, R.W., Lengauer, C., Herman, J.G., Kinzler, K.W., Vogelstein, B., Baylin, S.B., and Schuebel, K.E. 2000. CpG methylation is maintained in human cancer cells lacking DNMT1. Nature 404: 1003-1007.

Rideout, I.W., Eggan, K., and Jaenisch, R. 2001. Nuclear cloning and epigenetic reprogramming of the genome. Science 293: $1093-1098$

Riggs, A.D. 1975. X-inactivation, differentiation and DNA methylation. Cytogenet. Cell. Genet. 14: 9-25.

Riggs, A.D., Xiong, Z., Wang, L., and LeBon, J.M. 1998. Methylation dynamics, epigenetic fidelity and $\mathrm{X}$ chromosome structure. Novartis Found. Symp. 214: 214-225.

Robertson, K.D., Ait-Si-Ali, S., Yokochi, T., Wade, P.A., Jones, P.L., and Wolffe, A.P. 2000. DNMT1 forms a complex with $\mathrm{Rb}, \mathrm{E} 2 \mathrm{~F} 1$ and HDAC1 and represses transcription from E2Fresponsive promoters. Nat. Genet. 25: 338-342.

Rougier, N., Bourc'his, D., Gomes, D.M., Niveleau, A., Plachot, M., Paldi, A., and Viegas-Pequignot, E. 1998. Chromosome methylation patterns during mammalian preimplantation development. Genes \& Dev. 12: 2108-2113.

Russo, V.E.A., Martienssen, R.A., and Riggs, A.D. 1996. Epigenetic mechanisms of gene regulation. Cold Spring Harbor Laboratory Press, Cold Spring Harbor, NY.

Sado, T., Fenner, M.H., Tan, S.S., Tam, P., Shioda, T., and Li, E. 2000. $\mathrm{X}$ inactivation in the mouse embryo deficient for Dnmt1: Distinct effect of hypomethylation on imprinted and random X inactivation. Dev. Biol. 225: 294-303.

Selker, E.U. 1990. DNA methylation and chromatin structure: A view from below. Trends Biochem. Sci. 15: 103-107. 160.

Shemer, R., Hershko, A.Y., Perk, J., Mostoslavsky, R., Tsuberi, B., Cedar, H., Buiting, K., and Razin, A. 2000. The imprinting box of the Prader-Willi/Angelman syndrome domain. Nat. Genet. 26: 440-443.

Siegfried, Z., Eden, S., Mendelsohn, M., Feng, X., Tsuberi, B.Z., and Cedar, H. 1999. DNA methylation represses transcription in vivo. Nat. Genet. 22: 203-206.

Silva, A.J., Ward, K., and White, R. 1993. Mosaic methylation in clonal tissue. Dev. Biol. 156: 391-398.

Simmen, M.W., Leitgeb, S., Charlton, J., Jones, S.J.M., Harris, B.R., Clark, V.H., and Bird, A. 1999. Nonmethylated transposable elements and methylated genes in a chordate genome. Science 283: 1164-1167.

Smit, A.F. 1999. Interspersed repeats and other mementos of transposable elements in mammalian genomes. Curr. Opin. Genet. Dev. 9: 657-663.

Smith, S.S., Kan, J.L.C., Baker, D.J., Kaplan, B.E., and Dembek, P. 1991. Recognition of unusual DNA structures by human DNA(cytosine-5)methyltransferase. J. Mol. Biol. 217: 39-51.

Stancheva, I. and Meehan, R.R. 2000. Transient depletion of $\mathrm{xDnm} t 1$ leads to premature gene activation in Xenopus embryos. Genes \& Dev. 14: 313-327.

Stewart, C.L., Stuhlmann, H., Jahner, D., and Jaenisch, R. 1982. De novo methylation and infectivity of retroviral genomes introduced into embryonal carcinoma cells. Proc. Nat1. Acad. Sci. 79: 4098-4102.

Stöger, R., Kajimura, T.M., Brown, W.T., and Laird, C.D. 1997. Epigenetic variation illustrated by DNA methylation patterns of the fragile-X gene FMR1. Hum. Mol. Gen. 6: 17911801.

Swisher, J.F., Rand, E., Cedar, H., and Marie Pyle, A. 1998. Analysis of putative RNase sensitivity and protease insensitivity of demethylation activity in extracts from rat myoblasts. Nucleic Acids Res. 26: 5573-5580.

Szabo, P., Tang, S.H., Rentsendori, A., Pfeifer, G.P., and Mann, J.R. 2000. Maternal-specific footprints at putative CTCF sites in the H19 imprinting control region give evidence for insulator function. Curr. Biol. 10: 607-610.

Tada, M., Tada, T., Lefebvre, L., Barton, S.C., and Surani, M.A. 1997. Embryonic germ cells induce epigenetic reprogram- 
ming of somatic nucleus in hybrid cells. EMBO J. 16: 65106520.

Tamaru, H. and Selker, E.U. 2001. A histone H3 methyltransferase controls DNA methylation in Neurospora crassa. Nature 414: 277-283.

Tazi, J. and Bird, A. 1990. Alternative chromatin structure at CpG islands. Cell 60: 909-920.

Thomassin, H., Flavin, M., Espinas, M.L., and Grange, T. 2001. Glucocorticoid-induced DNA demethylation and gene memory during development. EMBO J. 20: 1974-1983.

Tremblay, K.D., Duran, K.L., and Bartolomei, M.S. 1997. A 5' 2-kilobase-pair region of the imprinted mouse H19 gene exhibits exclusive paternal methylation throughout development. Mol. Cell. Biol. 17: 4322-4329.

Turker, M.S. 1999. The establishment and maintenance of DNA methylation patterns in mouse somatic cells. Semin. Cancer Biol. 9: 329-337.

Tweedie, S., Charlton, J., Clark, V., and Bird, A. 1997. Methylation of genomes and genes at the invertebrate-vertebrate boundary. Mol. Cell. Biol. 17: 1469-1475.

Tweedie, S., Ng, H.-H., Barlow, A.L., Turner, B.M., Hendrich, B., and Bird, A. 1999. Vestiges of a DNA methylation system in Drosophila melanogaster. Nat. Genet. 23: 389-390.

Um, S., Harbers, M., Benecke, A., Pierrat, B., Losson, R., and Chambon, P. 1998. Retinoic acid receptors interact physically and functionally with the T:G mismatch-specific thymine-DNA glycosylase. J. Biol. Chem. 273: 20728-20736.

Venolia, L., Gartler, S.M., Wasserman, E.R., Yen, P., Mohandas, T., and Shapiro, L.J. 1982. Transformation with DNA from 5 azacytidine-reactivated X chromosomes. Proc. Natl. Acad. Sci. 79: 2352-2354.

Venter, J.C., Adams, M.D., Myers, E.W., Li, P.W., Mural, R.J., Sutton, G.G., Smith, H.O., Yandell, M., Evans, C.A., Holt, R.A., et al. 2001. The sequence of the human genome. Science 291: 1304-1351.

Viegas-Pequignot, E. and Dutrillaux, B. 1976. Segmentation of human chromosomes induced by 5-ACR (5-azacytidine). Hum. Genet. 34: 247-254.

Voo, K.S., Carlone, D.L., Jacobsen, B.M., Flodin, A., and Skalnik, D.G. 2000. Cloning of a mammalian transcriptional activator that binds unmethylated $\mathrm{CpG}$ motifs and shares a CXXC domain with DNA methyltransferase, human trithorax, and methyl-CpG binding domain protein 1. Mol. Cell. Biol. 20: 2108-2121.

Wakayama, T. and Yanagimachi, R. 2001. Mouse cloning with nucleus donor cells of different age and type. Mol. Reprod. Dev. 58: 376-383.

Walsh, C.P. and Bestor, T.H. 1999. Cytosine methylation and mammalian development. Genes \& Dev. 13: 26-34.

Walsh, C.P., Chaillet, J.R., and Bestor, T.H. 1998. Transcription of IAP endogenous retroviruses is constrained by cytosine methylation. Nat. Genet. 20: 116-117.

Wang, J., Mager, J., Chen, Y., Schneider, E., Cross, J.C., Nagy, A., and Magnuson, T. 2001. Imprinted $\mathrm{X}$ inactivation maintained by a mouse Polycomb group gene. Nat. Genet. 28: $371-375$.

Wassenegger, M., Heimes, S., Riedel, L., and Sanger, H.L. 1994. RNA-directed de novo methylation of genomic sequences in plants. Cell 76: 567-576.

Waugh O'Neill, R.J., O'Neill, M.J., and Marshall Graves, J.A. 1998. Undermethylation associated with retroelement activation and chromosome remodelling in an interspecific mammalian hybrid. Nature 393: 68-72.

Weiss, A., Keshet, I., Razin, A., and Cedar, H. 1996. DNA demethylation in vitro: Involvement of RNA. Cell 86: 709718 .
Weng, A., Magnuson, T., and Storb, U. 1995. Strain-specific transgene methylation occurs early in mouse development and can be recapitulated in embryonic stem cells. Development 121: 2853-2859.

Wigler, M., Levy, D., and Perucho, M. 1981. The somatic replication of DNA methylation. Cell 24: 33-40.

Wolffe, A.P., Jones, P.L., and Wade, P.A. 1999. DNA demethylation. Proc. Natl. Acad. Sci. 96: 5894-5896.

Woodcock, D.M., Lawler, C.B., Linsenmeyer, M.E., Doherty, J.P., and Warren, W.D. 1997. Asymmetric methylation in the hypermethylated CpG promoter region of the human L1 retrotransposon. J. Biol. Chem 272: 7810-7816.

Wutz, A. and Jaenisch, R. 2000. A shift from reversible to irreversible $\mathrm{X}$ inactivation is triggered during ES cell differentiation. Mol. Cell 5: 695-705.

Wutz, A., Smrzka, O.W., Schweifer, N., Schellander, K., Wagner, E.F., and Barlow, D.P. 1997. Imprinted expression of the Igf2r gene depends on an intronic $\mathrm{CpG}$ island. Nature 389: 745-749.

Xu, G.-L., Bestor, T.H., Bourc'his, D., Hsieh, C.-L., Tommerup, N., Bugge, M., Hulten, M., Qu, X., Russo, J.J., and ViegasPequignot, E. 1999. Chromosome instability and immunodeficiency syndrome caused by mutations in a DNA methyltransferase gene. Nature 402: 187-191.

Yates, P.A., Burman, R.W., Mummaneni, P., Krussel, S., and Turker, M.S. 1999. Tandem B1 elements located in a mouse methylation center provide a target for de novo DNA methylation. J. Biol. Chem. 274: 36357-36361.

Yoder, J.A., Walsh, C.P., and Bestor, T.H. 1997. Cytosine methylation and the ecology of intragenomic parasites. Trends Genet. 13: 335-340.

Zhang, Y. and Reinberg, D. 2001. Transcription regulation by histone methylation: Interplay between different covalent modifications of the core histone tails. Genes \& Dev. 15: 2343-2360.

Zhu, B., Zheng, Y., Angliker, H., Schwarz, S., Thiry, S., Siegmann, M., and Jost, J.P. 2000a. 5-Methylcytosine DNA glycosylase activity is also present in the human MBD4 (G/T mismatch glycosylase) and in a related avian sequence. Nucleic Acids Res. 28: 4157-4165.

Zhu, B., Zheng, Y., Hess, D., Angliker, H., Schwarz, S., Siegmann, M., Thiry, S., and Jost, J.-P. 2000b. 5-MethylcytosineDNA glycosylase activity is present in a cloned G/T mismatch DNA glycosylase associated with the chicken embryo DNA demethylation complex. Proc. Natl. Acad. Sci. 97: 5135-5139.

Zhu, B., Benjamin, D., Zheng, Y., Angliker, H., Thiry, S., Siegmann, M., and Jost, J.P. 2001. Overexpression of 5-methylcytosine DNA glycosylase in human embryonic kidney cells EcR293 demethylates the promoter of a hormone-regulated reporter gene. Proc. Natl. Acad. Sci. 98: 5031-5036. 


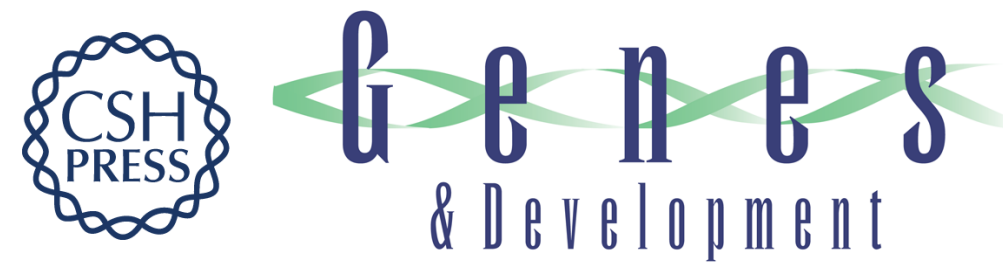

\section{DNA methylation patterns and epigenetic memory}

Adrian Bird

Genes Dev. 2002, 16:

Access the most recent version at doi:10.1101/gad.947102

References This article cites 197 articles, 70 of which can be accessed free at: http://genesdev.cshlp.org/content/16/1/6.full.html\#ref-list-1

License

Email Alerting Receive free email alerts when new articles cite this article - sign up in the box at the top Service right corner of the article or click here.

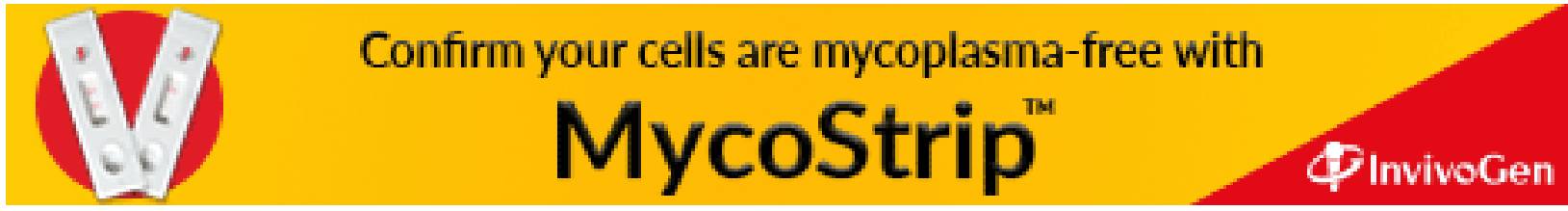

